Article

\title{
Implementing Regenerative Standards in Politically Green Nordic Social Welfare States: Can Sweden Adopt the Living Building Challenge?
}

\author{
Mara Forsberg ${ }^{1}$ and Clarice Bleil de Souza ${ }^{2, *(1)}$ \\ 1 Maram Architecture, Pryssgränd 10b, 11820 Stockholm, Sweden; Mara@maram.se \\ 2 Welsh School of Architecture, Cardiff University, Bute Building, King Edward VII Avenue, \\ Cardiff CF10 3NB, UK \\ * Correspondence: Bleildesouzac@cardiff.ac.uk; Tel.: +44-29-20875969
}

Citation: Forsberg, M.; Bleil de Souza, C. Implementing Regenerative Standards in Politically Green Nordic Social Welfare States: Can Sweden Adopt the Living Building Challenge? Sustainability 2021, 13, 738. https://doi.org/10.3390/ su13020738

Received: 8 December 2020 Accepted: 8 January 2021 Published: 14 January 2021

Publisher's Note: MDPI stays neutral with regard to jurisdictional clai$\mathrm{ms}$ in published maps and institutional affiliations.

Copyright: (C) 2021 by the authors. Licensee MDPI, Basel, Switzerland. This article is an open access article distributed under the terms and conditions of the Creative Commons Attribution (CC BY) license (https:// creativecommons.org/licenses/by/ $4.0 /)$.

\begin{abstract}
This paper focuses on understanding the place for regenerative building standards within the context of politically green Nordic social welfare states. To this end, it examines the particular case of adopting the Living Building Challenge (LBC), an iconic example of regenerative design standard, in Sweden. An extensive document analysis comparing the Swedish building and planning regulations as well as the Miljöbyggnad national certification system with the LBC, shows overlaps and barriers the standard can face when adopted in the country. Barriers are validated and further discussed in interviews with one of the few architects trying to achieve a certified LBC building in Sweden and Swedish public authorities from the Boverket (Swedish National Board of Housing, Building and Planning). Results from the document analysis and interviews show barriers to implement the LBC in Sweden are a product of a conscious political and ideological decision from the welfare state which considers infrastructure, and all its potential sustainable versions, a public good to be provided to all and funded by all. This premise contrasts with the self-sufficient approach promoted by the LBC, which in this particular aspect, can be interpreted as a threat to the welfare state.
\end{abstract}

Keywords: sustainability in the welfare state; urban regeneration in Nordic countries; sustainable and regenerative infrastructure; sustainable and regenerative policies; sustainability and regeneration

\section{Introduction and Background}

This paper assesses if regenerative building standards could potentially complement the existing legislation, regulations, and standards used in politically green Nordic social welfare states. It focuses on discussing what the Living Building Challenge (LBC), an iconic example of regenerative standard, could add to the Swedish context by analysing its building and planning regulations as well as the Miljöbyggnad national certification system outlining gaps and overlaps in their implementations. Outputs of the study will illustrate what contributions the LBC would provide to the Swedish regulatory context as well as what barriers the Swedish regulatory system would impose to its implementation, with an attempt to identify what are the reasons behind these barriers.

Green building standards have been actively developed and used towards improving design and construction practices with increased demand during the past 10 years and expected continuous growth in the future [1]. They are considered effective tools to help practitioners and the building industry in general to position their products in the market, aiding the choice of sustainable design and construction principles and creating a unified understanding about quality control for design solutions. Popular standards include the pioneer BREEAM (Building Research Establishment Environmental Assessment Method), the LEED (Leadership in Energy and Environmental Design), the GreenBuilding, to cite a few. These standards are criticized for not being effective enough in responding to growing sustainability and environmental issues. 
Recently, they have been surpassed by more comprehensive standards which are centred in assessing buildings in use and contain more stringent targets in relation to environmental protection. They request not only that projects are sustainable but also restore and/or regenerate the site and context to its original condition and beyond $[2,3]$. These standards require integrated design proposals substantiated by several pieces of evidence, from documentation and simulation up to energy metering and indoor air quality control. One of such standards is the Living Building Challenge (LBC), which differs from currently more popular rating systems by evaluating actual performance after 12 months of use, rather than the intended one expressed in the design phase [4].

The LBC does not contain any methodology, workflow or tool to reach compliance but is structured around a set of imperatives which are supposed to be applied to either new or existing buildings, interior, landscape and infrastructure [5]. Considered to be the most rigorous and demanding assessment system currently in the industry, it requires buildings to be net-zero, not only guaranteeing energy supply via renewables in-situ but also providing all of its water supply and manage all of its grey and black water on-site in addition to guaranteed access to nature and the incorporation of biophilic design [6]. Its outreach is global as the approach is deemed flexible enough to be applied in various climate zones and countries with their own characteristics and national preferences [5].

However, in addition to well documented barriers faced by sustainability standards such as cost [7], lack of knowledge and experience [7-9] as well as time to gather the necessary information required for accreditation [9], regenerative standards are also criticized by a series of other reasons. These include: their lack of clarity in relation to what is considered a positive contribution [10] and how it can be assessed [11]; being questionable in terms of their efficiency [12]; having aims too ambitious to be adopted by designers without systemic thinking and ecological frameworks [13]; raising issues related to the scale of the proposed solution which normally is too small to provide clear ecological benefits [14] as well as feasibility in relation to how they can be inserted in the existing context of cities and neighborhoods [12].

A notable barrier related to the implementation of the $\mathrm{LBC}$ are national regulatory requirements, specifically regulations and codes related to water provision and discharge which prioritize centralized supply with assumed cost-effective maintenance and control, making it difficult for project teams to use on-site water and sewerage systems [15]. Another barrier is water quality control, as many states and local authorities require all water entering building premises to be of drinking quality, thus preventing grey water re-use for other purposes such as toilet flushing or washing machines [15]. With regards to energy supply, regulations often prioritize the connection with the grid with no incentives for the installation of small and individual on-site renewable energy systems let alone feedback to the grid [15]. Reasons emphasized by [15] are assumed to be related to the risk aversion of regulatory bodies in relation to embracing innovative technological approaches to design and construction in favor of existing and traditional practices. While stringent and outdated building policy can be a significant barrier for sustainable and innovative construction, obstacle can also include a lack of clear codes and directives that would help organizations to attract investment in green technology businesses and hence develop the industry further [7]. These regulatory barriers were mainly documented in the North American context, through an analysis of case studies from the USA and Canada in relation to mandatory regulatory requirements for project approval, from interviews with project teams as well as other industry stakeholders [15].

To the best of the authors' knowledge there are no studies documenting regulatory challenges and barriers to implement regenerative standards in the European context. There are also no studies identifying potential overlaps between EU regulatory frameworks and the LBC standard which could potentially make parts of it redundant and therefore discourage its implementation in the European scenario. This paper attempts to provide a contribution to this knowledge gap by assessing barriers and overlaps in implementing the LBC in Sweden particularly looking at its regulatory framework and sustainability 
standards currently implemented in the market in combination with interviews with professionals from Swedish building regulation institutions and a practitioner involved in one of the first Swedish LBC accreditation process but still in the initial design stages. It provides results that can be useful to designers willing to use the LBC in the Swedish context, to representatives of the LBC or other sustainability standards aiming to penetrate the Swedish market as well as to public authorities and researchers trying to understand how regulations and green standards interact in practice.

The paper starts by providing an overview of the different green standards adopted by the Swedish market quantitatively illustrating the place of the Miljöbyggnad national certification system in face of others. It then, provides an overview of the Swedish regulatory framework explaining its different layers, from the EU to municipalities level, as well as the different types of agents responsible for implementing it in a complex and interwoven devolved system. It follows with an extensive document analysis of the Swedish regulations and the Miljöbyggnad comparing them with the LBC outlining gaps and overlaps in a summary table, discussing them one-by-one using the LBC framework as a guidance to facilitate comparison. It validates the gaps from the document analysis through interviews with one architect involved in an LBC project in Sweden plus three public authorities from the Boverket (Swedish National Board of Housing, Building and Planning) unfolding and discussing the reasons behind them, concluding they are actually different from those identified by North American studies.

\section{Materials and Methods}

The LBC is currently the least popular standard in Sweden with no records of any full LBC certification already granted in the country. However, there are currently a few projects that are designed according to the system and will be on the way to be certified soon, as well as a series of seminars and events organised by the LBC to promote the adoption of the standard in the country. Contrarily to the work done by [15], this research adopted a document analysis approach followed by a set of semi-structured interviews to record overlaps and barriers in relation to the implementation of the LBC in Sweden.

The document analysis started by examining the Swedish regulatory system, through an in-depth reading of the following documents: the Boverket's Building Regulations (BBR), Planning and Building Act, Environmental code and related environmental regulations followed by an analysis of the Miljöbyggnad national certification system, widely adopted by the Swedish market. LBC documents examined comprised the official report 'Living Building Challenge 4.0' [5] and all its corresponding Handbooks (Handbooks for the newest version 4.0 were not available at the time this research was undertaken, therefore authors have used handbooks of the previous version 3.1).

A number of questions were raised from the document analysis and put forward into a set of semi-structure interviews to be conducted with architects who were working with the LBC system, professionals within municipalities who are responsible for issuing building permits, and professionals from the main national Swedish building regulations authority, who are responsible for building regulations approvals.

From the two currently known ongoing LBC projects in Sweden, only one architect agreed to be interviewed. Questions directed towards this architect were therefore designed to better understand his/her experience to work with each of the LBC petals verifying barriers and overlaps with the regulatory system and the Miljöbyggnad national standard certification system from a practitioners' perspective. In order to learn about the practical aspects of handling LBC requirements within Swedish municipalities in relation to how they overlap or contradict interpretations of the national regulations, six professionals responsible for handling building permits were approached to be interviewed but all of them declined the invitation. Insights from the public sector in relation to barriers and overlaps between the LBC and the Swedish regulations were then seek at higher level by interviewing three members of the central government, specifically from the Swedish National Board of Housing, Building and Planning (Boverket), the central government authority in 
planning and building regulations. Semi-structured interviews with representatives of the Boverket were undertaken after the interview with the architect, enabling further questions to be added to the public authorities from the previous interview findings.

Findings from the document analysis and interviews were examined and reported following the certification categories proposed by the LBC: Place, Water, Energy, Health + Happiness, Materials, Equity and Beauty. Each 'Petal' has a set of imperatives and targets which are mandatory to achieve certification and therefore provide a comprehensive set of themes to analyse overlaps and barriers with the Swedish regulatory framework and the Miljöbyggnad national certification standard. Overlaps and barriers are summarized in a table and recalled in the section following it which validates document analysis findings through interviews and discusses them highlighting the potential contribution the LBC could add to the Swedish context. A short description of the Miljöbyggnad and the Swedish regulatory system is provided before the results analysis section to contextualize the research.

\section{The Miljöbyggnad Sustainability Standard and the Swedish Regulations}

The most common green building standards adopted in Sweden are the LEED, BREEAM-SE (Swedish version of BREEAM adapted to comply with national building codes and regulations) and the Miljöbyggnad [16]. The latter is the Swedish national sustainable building certification system and by far the most popular one, with 547 certified buildings and 659 preliminarily certified buildings across the country [17]. It is owned and managed by the Swedish Green Building Council (SGBC) and was adapted to the Swedish climate and construction environment, rooted in the national construction and sustainability regulation context [18]. By the end of 2019, 73\% of buildings certified with Miljöbyggnad have Silver rating, 15\% Bronze rating and 12\% Gold one [17]. Most of the certified or preliminary certified projects are apartment buildings ( $54 \%$ ), followed by offices (21\%), other types buildings (18\%) and shops (10\%) [17].

The Miljöbyggnad 3.0 (at the time this research was done Miljöbyggnad 3.1 was not available, therefore authors have used the previous version 3.0) has three sections (energy, indoor environment and materials) and 16 assessment categories which include contribution to environmental quality, cost effectiveness and user friendliness [19] stretching a bit beyond sustainability towards including environmental quality and well-being. Similarly, to the LBC, buildings are only issued verified certification after in use, with the Miljöbyggnad requiring 24 months of use to be certified in contrast with the 12 months required by the LBC. Like with the LBC, the Miljöbyggnad also requires compliance with all its assessment criteria but provides different degrees for these to be implemented, awarding a bronze, silver or gold category accordingly [19]. In this sense the Miljöbyggnad might have labels looking like the LEED or BREAM ones but their meaning is different as this rating system is not based on a product of weighted key performance indicators avoiding certain criteria to be chased for the sake of increasing credit value [20]. The focus of the Miljöbyggnad is clearly on buildings and construction and its scope is complementary to the Swedish regulations.

The Swedish regulatory framework has four different hierarchical layers: European Union (EU) layer, Country or national layer, Regional layer, and Municipal layer. The EU layer is translated into the Swedish Building Regulations document called Boverket Building Regulations (BBR), which is applied at national and regional levels [21] and refers to planning as well as building construction. Issued by the Swedish National Board of Housing, Building and Planning governmental authority in 1988, the BBR covers: general rules for planning; accessibility, dwelling design, room height, utility rooms; mechanical resistance and stability; safety in case of fire; hygiene, health and environment; protection against noise; safety in use; and energy management [21] (Boverket's Building Regulations are regularly updated, and the current version of the law is 'BFS 2011:6 with amendments up to 2020:4' [21]). 
However, the BBR is rather basic in relation to environmental performance and sustainability [22]. They, therefore, refer to other codes such as those issued by the Swedish Agency for Marine and Water Management (for matters such as sewerage and water management), the Swedish Environmental Protection Agency for the Swedish Environmental Code, and others. They also refer to few EU directives such as Regulation (EC) No 1907/2006 of December 182006 regarding chemical substances and chemicals in goods [23].

National policies also include the Planning and Building Act (PBL in Swedish) [24]. The PBL is a law issued by the Swedish parliament or 'Riksdag' [25], which directly applies to municipalities stating they are obliged to have a comprehensive plan of the future use and development of their land and water following PBL regulations. The Boverket or Swedish National Board of Housing, Building and Planning is also responsible for ensuring that the PBL is embodied in any municipality development plan. However, this comprehensive municipality plans are not legally binding only the detailed development plans, which municipalities have to prepare for specific areas before any planned construction work takes place [24].

The main task of municipalities is to plan urban development, issue building permits, as well as act as a developer by commissioning public projects such as hospitals, schools, roads and bridges [25]. There are 290 municipalities in Sweden and apart from acting as gate keepers for project approval, they also offer valuable support such as software tools, training, and databases. They support project teams to select appropriate environmental measures and have at least one energy and climate advisor among their staff [25].

Building permits are issued by the municipal building committees, which could also supervise project teams during the construction stages [21]. Permits are needed for new constructions, extensive renovations and extensions, from buildings to minor interventions such as fences [21]. In addition to building permits, project teams often need to apply for environmental permits, handled by environmental committees also within the municipalities. The processing of building permit applications comprises compliance with regulations as well as public consultations [21]. After permits are granted, municipalities might also want to discuss construction and planning issues in technical consultations. The municipal building committee will inspect construction works at three different stages (beginning, near to completion and right after completion) issuing clearance after a successful final inspection [21].

The PBL requires municipalities to ensure that built environment and construction works have "long-lasting and effective management of land, water areas, energy resources and raw materials" [24]. In this regulatory structure, most decision making is devolved, granting municipalities authority and control mainly with regards to environmental management, infrastructure provision, land use beyond just the granting of project approval.

\section{Document Analysis Results: The LBC within the Swedish Context}

Table 1 provides an overview of the document analysis undertaken, highlighting in green and red text respectively clear overlaps and barriers between the Swedish regulations and the LBC. Findings per LBC petal are discussed in this section one by one explaining how overlaps and barriers were unfolded, with the addition of EU regulations, directives, and standards when necessary. 


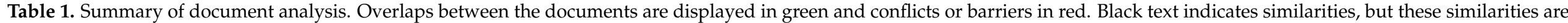
not comprehensive to the whole set of regulations.

\begin{tabular}{|c|c|c|c|c|c|c|}
\hline \multicolumn{2}{|r|}{ Living Building Challenge (LBC) } & \multirow[b]{2}{*}{$\begin{array}{l}\begin{array}{c}\text { Environmental Code \& } \\
\text { Related Environmental } \\
\text { Regulations }\end{array} \\
\\
\text { Safeguards undeveloped } \\
\text { land; } \\
\text { Protects unspoiled natural } \\
\text { habitats, endangered or } \\
\text { valuable fauna and flora; } \\
\text { Safeguards agricultural } \\
\text { land; } \\
\text { Regulates development in } \\
\text { hazardous land \& } \\
\text { remediated brownfields; }\end{array}$} & \multirow{2}{*}{\begin{tabular}{|l} 
Planning and Building \\
Act (PBL) \\
\\
\\
\\
Demands open spaces \\
for outdoor activities \\
in residential and \\
school projects
\end{tabular}} & \multirow[b]{2}{*}{\begin{tabular}{|l}
\multicolumn{1}{c}{ Boverket } \\
\\
\\
Promotes densification of \\
cities; \\
Limits sub-urban growth; \\
Promotes integrated public \\
transport through nodal \\
points within regional cores;
\end{tabular}} & \multirow[t]{2}{*}{ Miljöbyggnad } & \multirow{2}{*}{$\begin{array}{l}\begin{array}{c}\text { Municipality } \\
\text { Development } \\
\text { Plans }\end{array} \\
\\
\text { Municipalities } \\
\text { decide upon } \\
\text { provision of } \\
\text { urban agriculture; } \\
\text { Promote the } \\
\text { integration of } \\
\text { public transport } \\
\text { with cycling } \\
\text { and walking; }\end{array}$} \\
\hline$\frac{\mathbb{U}}{\tilde{I}}$ & $\begin{array}{l}\text { Safeguards undeveloped land } \\
\text { and prime farmland; } \\
\text { Develop in previously } \\
\text { developed land including } \\
\text { monoculture agriculture; } \\
\text { Develops away from } \\
\text { environmentally protected areas; } \\
\text { Provides urban agriculture, } \\
\text { medicinal plants, or beekeeping; } \\
\text { Protects or restores land to its } \\
\text { original conditions; } \\
\text { Expands and protects natural } \\
\text { wildlife away from the site; } \\
\text { Develops measure to encourage } \\
\text { walking and cycling }\end{array}$ & & & & & \\
\hline$\frac{\overline{ \pm}}{\stackrel{ \pm}{3}}$ & $\begin{array}{l}\text { In-situ water harvesting from } \\
\text { multiple sources; } \\
\text { Reduce water consumption to } \\
50 \% \text { in comparison to } \\
\text { regional baseline; } \\
\text { Do not exceed site hydrological } \\
\text { carrying capacity; } \\
\text { In-situ management of } \\
\text { stormwater, greywater } \\
\text { and blackwater }\end{array}$ & $\begin{array}{l}\text { Prescribes location } \\
\text { for wastewater } \\
\text { treatment plants; } \\
\text { Groundwater collection } \\
\text { and wastewater treatment } \\
\text { can not cause damage to } \\
\text { human health and } \\
\text { the environment }\end{array}$ & $\begin{array}{l}\text { Devolves decisions on } \\
\text { wastewater treatment and } \\
\text { water harvesting to } \\
\text { municipalities; }\end{array}$ & $\begin{array}{l}\text { Allows greywater to be used } \\
\text { in flushing toilets, washing } \\
\text { machines, heating, etc.; } \\
\text { Stormwater to be drained } \\
\text { away from site; } \\
\text { Private sewerage systems } \\
\text { have to follow rules by } \\
\text { Swedish Environmental } \\
\text { Protection agency; } \\
\text { Prescribes to design } \\
\text { appropriate water systems to } \\
\text { ensure water quality and } \\
\text { public health; } \\
\text { Buildings have to be designed } \\
\text { to avoid damage by moisture; } \\
\text { suggests to follow industry } \\
\text { rules }\end{array}$ & $\begin{array}{l}\text { Prescribes to design appropriate } \\
\text { water systems, regular control and } \\
\text { monitoring to avoid Legionella. } \\
\text { Buildings have to be designed to } \\
\text { avoid damage by moisture; } \\
\text { For moisture and water safety } \\
\text { prescribes to follow industry rules }\end{array}$ & $\begin{array}{l}\text { Water is considered } \\
\text { key national interest; } \\
\text { Control access to } \\
\text { potable water, } \\
\text { wastewater and } \\
\text { sewerage grids } \\
\text { and treatment; } \\
\text { City-scale } \\
\text { stormwater } \\
\text { treatment in } \\
\text { some areas } \\
\text { (e.g., Stockholm) }\end{array}$ \\
\hline
\end{tabular}


Table 1. Cont.

\begin{tabular}{|c|c|c|c|c|c|c|}
\hline 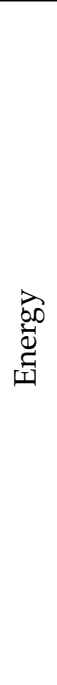 & $\begin{array}{l}\text { Demand reduction of } 70 \% \text { in } \\
\text { relation to regional base case; } \\
\text { In-situ renewable energy } \\
\text { generation covering } 105 \% \text { of } \\
\text { annual energy use; } \\
\text { Residential storage of } 10 \% \text { of } \\
\text { weekly lighting load; } \\
20 \% \text { of demand reduction } \\
\text { coming from embodied energy } \\
\text { in construction }\end{array}$ & $X$ & $\begin{array}{l}\text { Prescribes efective and } \\
\text { long lasting management } \\
\text { of energy resources }\end{array}$ & $\begin{array}{l}\text { Limits for heat loss, low } \\
\text { cooling demands, efficient use } \\
\text { of heating \& cooling and } \\
\text { efficient use of electricity; } \\
\text { Flexible system of large scale } \\
\text { and micro-scale renewable } \\
\text { energy generation; } \\
\text { Energy surplus transferred } \\
\text { back to the grid; }\end{array}$ & $\begin{array}{l}\text { Prescribes that buildings have to be } \\
\text { designed to avoid heat loss; } \\
\text { Buildings cannot exceed the use of } \\
\text { energy set by BBR. To achieve gold } \\
\text { certification, residential buildings } \\
\text { cannot use more than } 70 \% \text { of } \\
\text { energy set by BBR, whereas } \\
\text { non-residential buildings cannot } \\
\text { use more than } 60 \% \text { of energy set } \\
\text { by BBR. } \\
\text { To achieve gold, at least } 80 \% \text { of } \\
\text { energy supply coming from } \\
\text { renewables with } 5 \% \text { of it generated } \\
\text { on site to achieve gold certification; } \\
\text { Rewards reduced embodied } \mathrm{CO}_{2} \\
\text { related to EPD (Environmental } \\
\text { Product Declaration) of } \\
\text { the building. }\end{array}$ & $X$ \\
\hline 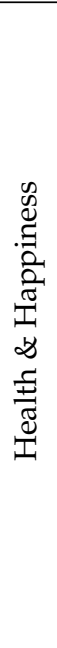 & $\begin{array}{l}\text { User-centric building operation; } \\
\text { Certify buildings after } \\
12 \text { months in operation; } \\
\text { Daylight for a minimum of } 75 \% \\
\text { of all spaces regularly used; } \\
\text { Indoor air quality targets mainly } \\
\text { related to indoor air pollution; } \\
\text { Refers to ASHRAE } 62 \\
\text { for ventilation; } \\
\text { Use design strategies } \\
\text { which promote } \\
\text { human-nature interactions }\end{array}$ & $X$ & $\begin{array}{l}\text { Prescribes inspection } \\
\text { of ventilation systems } \\
\text { to ensure satisfactory } \\
\text { air quality and } \\
\text { indoor climate }\end{array}$ & $\begin{array}{l}\text { Requirements for indoor air } \\
\text { quality, light and ventilation; } \\
\text { Prescribes air flow, } \\
\text { temperature and moisture } \\
\text { levels; Recommends views to } \\
\text { outdoors }\end{array}$ & $\begin{array}{l}\text { Certifies buildings after } 24 \text { months } \\
\text { in operation; } \\
\text { Prescribes targets and calculation } \\
\text { methods for indoor climate in } \\
\text { summer and winter; User-centric } \\
\text { window and door operation; } \\
\text { The 'Moisture safety' section } \\
\text { rewards buildings designed, built, } \\
\text { and managed to reduce the risk of } \\
\text { internal and external moisture and } \\
\text { water damage; } \\
\text { Discourages the use of cooling } \\
\text { systems in the summer through } \\
\text { reducing solar gains; } \\
\text { Imposes minimal average daylight } \\
\text { factor of at least } 1.5 \% \text {; promotes } \\
\text { views to outdoors }\end{array}$ & $X$ \\
\hline
\end{tabular}


Table 1. Cont.

\begin{tabular}{|c|c|c|c|c|c|c|}
\hline $\begin{array}{l}\frac{0}{\pi} \\
\frac{\pi}{0} \\
\stackrel{\pi}{\pi} \\
\sum\end{array}$ & $\begin{array}{l}\text { Forbids the use of materials } \\
\text { with greatest impact in } \\
\text { human and ecosystem health; } \\
\text { Requires extensive } \\
\text { material documentation; } \\
\text { Request for total embodied } \\
\text { carbon of the project to be offset } \\
\text { via purchasing from an } \\
\text { approved provider; } \\
\text { Requests content, origin, and } \\
\text { fair extraction of materials } \\
\text { to be proven; } \\
\text { Requests the use of materials } \\
\text { close to the project site; } \\
\text { Focuses on durability, } \\
\text { adaptability, and re-use of new } \\
\text { materials with their } \\
\text { re-integration to the nutrient } \\
\text { loop at the end of life }\end{array}$ & $\begin{array}{l}\text { Encourages materials } \\
\text { re-use and recycling; } \\
\text { Encourages responsible } \\
\text { management of raw } \\
\text { materials to ensure } \\
\text { that natural cycles } \\
\text { are preserved; }\end{array}$ & $X$ & $\begin{array}{l}\text { Materials and their treatment } \\
\text { should not affect indoor and } \\
\text { local environmental } \\
\text { conditions negatively; } \\
\text { Prioritize the use of } \\
\text { non-toxic materials; } \\
\text { Comply with targets from the } \\
\text { Registration, Evaluation, } \\
\text { Authorisation and Restriction } \\
\text { of Chemicals (REACH); } \\
\text { Overall recommendations for } \\
\text { durability and strength; }\end{array}$ & $\begin{array}{l}\text { Requires extensive documentation } \\
\text { in relation to materials and } \\
\text { their safety; } \\
\text { Buildings are limited to use } \\
\text { potentially harmful materials listed } \\
\text { by REACH; } \\
\text { Praises reduced embodied } \mathrm{CO}_{2} \\
\text { related to EPD. }\end{array}$ & $X$ \\
\hline 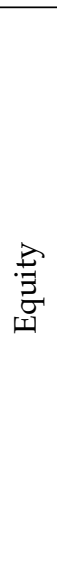 & $\begin{array}{l}\text { Restricts size and percentage } \\
\text { of land use for car parking; } \\
\text { Create places with universal } \\
\text { accessibility (universal access } \\
\text { to nature, fresh air, and } \\
\text { solar rights); } \\
\text { Requires } 0.1 \% \text { of project } \\
\text { investment cost to be donated to } \\
\text { charity or include stakeholders } \\
\text { from disadvantaged } \\
\text { communities to any of } \\
\text { project phases; } \\
\text { Requests disclosure of business } \\
\text { practices in relation to social } \\
\text { responsibility and justice }\end{array}$ & $X$ & $\begin{array}{l}\text { Buildings and sites have } \\
\text { to be accessible for all } \\
\text { social groups; When } \\
\text { insufficient space on site, } \\
\text { prioritizes open space } \\
\text { over parking; Devolves to } \\
\text { municipalities rights to } \\
\text { decide upon parking }\end{array}$ & $\begin{array}{l}\text { Promotes the reduction in the } \\
\text { use of cars, including charges } \\
\text { and physical measures; } \\
\text { Regulates on accessibility for } \\
\text { people with disabilities; }\end{array}$ & $X$ & $\begin{array}{l}\text { Municipalities } \\
\text { might have specific } \\
\text { requirements with } \\
\text { this regard }\end{array}$ \\
\hline
\end{tabular}


Table 1. Cont.

\begin{tabular}{|c|c|c|c|c|c|c|}
\hline $\begin{array}{l}\underset{\vec{D}}{\vec{J}} \\
\text { ص్ }\end{array}$ & $\begin{array}{l}\text { Asks to incorporate biophilic } \\
\text { and aesthetics elements as well } \\
\text { as public art into } \\
\text { a building project } \\
\text { to promote delight and } \\
\text { celebration of culture, spirit, and } \\
\text { place; Survey users in relation to } \\
\text { project design; } \\
\text { Request project team to disclose } \\
\text { and provide information on } \\
\text { building performance and } \\
\text { operation to the public }\end{array}$ & $x$ & $\begin{array}{l}\text { Asks for purposeful and } \\
\text { aesthetically pleasing } \\
\text { built environment; } \\
\text { Devolves to } \\
\text { municipalities the rights } \\
\text { to decide on building } \\
\text { aesthetics, green spaces, } \\
\text { and transportation routes }\end{array}$ & $\begin{array}{l}\text { During the construction or } \\
\text { alteration of buildings, } \\
\text { recommends to consider } \\
\text { buildings' cultural and } \\
\text { aesthetical values }\end{array}$ & $X$ & $\begin{array}{l}\text { Municipalities } \\
\text { might have specific } \\
\text { requirements with } \\
\text { this regard }\end{array}$ \\
\hline
\end{tabular}




\subsection{Place}

The LBC first imperative of the 'Place' petal is centred in environmental protection, meaning construction can only take place in previously developed land, grey fields, or brown fields and needs to be sufficiently apart from environmentally protected areas such as wetlands, old-grown forests, etc. unless if specifically connected to the protection of these sites $[5,26]$. In essence, none of the Swedish regulations go against the idea of safeguarding undeveloped land. The Environmental Code has a whole chapter about protection of nature ruling the land use of private area safeguarding development in unspoiled natural habitats, protecting endangered or valuable fauna and flora, etc. [27]. It states that large land and water areas, which so far have not been affected by construction projects or other intrusions, have to be protected and safeguarded against activities that can affect and change their natural appearance and character Kap.3, §2 [27] and does not allow construction on agricultural lands, unless the project "safeguards significant national interests where this need cannot be met satisfactorily from the point of view of public interest by using other land" Kap.3, §4 [27]. While the LBC also protects prime farmlands, it considers monoculture agriculture a suitable place for development and therefore, can potentially clash with the Swedish law in this respect [26]. In addition, Swedish regulations limit activities in hazardous zones which can threat human health and allow projects to be developed in remediated brownfields if following measures stated in the Environmental Code Kap10, §1-8 and §10-14 [27] respectively. The LBC refers to credible authority for assessment and remediation measures in these cases [5,26].

The 'Urban agriculture' imperative requires projects to incorporate areas dedicated to urban agriculture and/or medicinal plants and be-keeping, with two weeks self-sufficiency for residential developments, unless the project's main purpose is to protect the land where it is being developed or restore it to its original conditions [26]. Sweden does not have any law or regulation specifically related to urban agriculture. General agriculture in Sweden is regulated by the Board of Agriculture, which follows EU agriculture policy [28]. The European Parliamentary Research Service issued an in-depth analysis on urban agriculture in Europe [29] and recognized that EU has not been very supportive in promoting urban farming, with the Common Agricultural Policy [30] mainly emphasizing the development of rural agriculture and farmers through various support systems, such as financing, supply chain organizations, investments in innovation and trainings, etc. Also, a document issued by Boverket on urban density recommends city densification and is against outward city growth [21], potentially hindering the allocation of open space for agriculture within cities. In principle, there should be no restrictions in exploring vertical agriculture, roof gardening or indoor farming, such as use of hydroponic or aquaponic systems. This would therefore ultimately depend on what is stated in each municipality development plan as they can regulate land use for greenery and building density [24]. For instance in the municipality of Malmö there are initiatives such as the 'Seved' urban gardening network which promotes urban agriculture by fostering community, environmental and educational goals as part of the EU COST Action 'Urban Agriculture Europe' [31]. This includes requirements for on-site car parking and/or spaces for loading/unloading as per PBL Kap.4, $\$ 13$ reducing green and agricultural areas [24]. They, however, have to follow the PBL with regards to the allocation of large open space for outdoor activities for residential and school projects without being allowed to give priority to car parking in these cases [24]. Nevertheless, car-parking continues to be a controversial problem because despite a decrease in inner city traffic flows due to the adoption of shared cars ownership and the use of carpooling, city densification pushes for an increase in shared car parking spaces [32].

The LBC third imperative 'Habitat exchange' which focuses on protection and expansion of existing natural areas [26], demanding protection of wildlife outside the project site through investments in approved conservation organizations has no equivalent requirement in any Swedish regulation, despite the Environmental Code being strict in relation to protecting unspoiled natural habitats, endangered or valuable fauna and flora. The same can be stated for the last imperative of this section 'Human scaled living' which demands 
projects to provide specific measures to encourage building environments that support walking, cycling and reduce the use of vehicles on site [26]. However, a document issued by Boverket in 2014 'Vision for Sweden 2025' provides recommendations for city based on reducing the number of cars, promoting the use of public transport systems (mainly rail connections with nodal points within regional cores), extensive cycle routes and footpaths [32]. One of such examples is Uppsala municipality's detail plan for Rackaberget area [33], in legal force since 2018, which safeguards its bicycle roads, and has already implemented a new city bus line network [33].

It also includes charges and other physical measures to limit the use of motor traffic vehicles and the promotion of bringing bicycles to emphasize walking, cycling and public transport [32]. This means once municipalities provide more sustainable mobility infrastructure, end-users are expected to adopt it.

\subsection{Water}

The LBC 'Water' petal imperatives 'Responsible water use' and 'Net positive water' ask for respecting the carrying capacity of the natural ecosystem emulating, as much as possible, the local hydrologic cycle. In addition, the official report $[5,34]$ states the water footprint should be $50 \%$ lower that the regional baseline. This means the project team needs to demonstrate it can supply the building with on-site sourced water for 12 months (with monthly metering demonstrating the different supply sources) and that the overall target footprint must not be higher than the natural capacity of the site as well as 50\% of the regional baseline. In addition, this petal requires in-situ stormwater, greywater and blackwater management as well as in-situ water harvesting from the rain, underground, condensation, surface sources and/or recycling for grey and blackwater after treated on-site for re-use [34]. Connecting to the potable water grid is only allowed if the municipality enforces it and/or if the aquifer is inaccessible or contaminated but can only be done for potable uses within the acceptable carrying capacity of the site. Connecting to the municipal sewer grid is allowed in certain cases but the treated water must return to the site for use so long as the municipality has a biologically based treatment rather than a chemical one [34].

To the best of the authors knowledge, at the time of this study, there were no requirements for the reduction of water consumption in the Swedish regulations or in the EU Drinking Water Directive [35]. However, the European Commission's report on optimizing water reuse in Europe, published in 2015, shows incentives in developing projects and legislation to support reuse of water, [36], meaning they would be supportive to this endeavor.

Despite the BBR not directly addressing water recycling, it does allow grey water to be used for flushing toilets, washing machines, heating, etc. [21]. The Boverket is, however, clear that buildings and their installations shall be designed to ensure water quality and hygiene conditions satisfy public health requirements [21]. The Environmental Code's Kap.9, §10 states that groundwater collection systems have to ensure safety to human health [27], and the Miljöbyggnad requires appropriate design for water systems as well as regular water monitoring to avoid Legionella [19], meaning they do not explicitly go against water treatment in-situ.

However, the Environmental Code’s Kap.11, §6 states that "Water operations may only be undertaken if the benefits from the point of view of public and private interests are greater than the costs and damages associated with them" [27]. In addition, the "Vision Sweden 2025' states the municipal water supply system has been recently updated and risk-assessed in relation to quality and security, including the possibilities of exporting the surplus to other countries [32]. Water consumption is controlled at district scale. "All water bodies that are used for extraction of drinking water, exceeding $10 \mathrm{~m}^{3}$ per day, or that are used for more than 50 persons, are subject to survey and are areas entitled to water protection measures" [32] and drinking water supply is considered of key national interest. 
In relation to stormwater management, the Boverket states that "Surface water installations shall be able to drain away rainwater and meltwater to ensure the risk of flooding, accidents or damage to buildings and the ground are limited" [21]. The "Vision Sweden $2025^{\prime}$ promotes the creation of multifunctional outdoor urban spaces "to contribute to evening out water flows in the city (urban runoffs)" [32]. Thus, it is not uncommon to see city-scale sustainable blue-green water systems in place. For instance, Stockholm has adopted a strategy for integrating stormwater management into its infrastructure with the use of various natural infiltration systems and water diversion systems [37], a type of collective initiative also promoted in rural areas [32].

As for wastewater treatment, $95 \%$ of urban areas receive a combination of biological and chemical treatment and on-site small-scale sewage plants are already widely used for buildings in rural areas, where municipal sewerage networks are not available [38]. As there is significant negative effect such as eutrophication of lakes and coastal water areas due to nitrogen and phosphorus released from these small-scale systems, rules towards them are strict [38]. The Swedish Agency for Marine and Water management regulations HVMFS 2016:17 [39] addresses wastewater health protection issues and states its discharge cannot cause contamination of groundwater or drinking water [39]. The regulations also give detailed information about the location and placement of wastewater treatment plants with regards to buildings, plot boundaries, groundwater level, water areas and water sources [39], but do not address the type of system private sewerage treatment plants could use.

Similarly, to the 'Place' petal, the success of implementation of the 'Water' petal can be largely affected by the location of the project site. The PBL devolves to municipalities the control to locate new construction development primarily in areas that have access to potable water and sewerage facilities, transport, and other public services [24] and this, in combination with the Boverket limits to suburban growth and promotion of inner cities densification, discourage in-situ management of potable water and wastewater of all sorts.

\subsection{Energy}

The LBC 'Energy' petal imperatives are 'Energy + carbon reduction' and 'Net positive carbon' which includes demand reduction, reliance on renewable sources and creation of a decentralized and safe infrastructure [5]. More specifically, the standard prescribes new buildings need to be $70 \%$ less energy intensive than the equivalent baseline building type, with $20 \%$ of it being associated to embodied energy in construction. In addition, in-situ renewable energy production needs to cover $105 \%$ of annual energy use, with residential buildings able to store $10 \%$ of the weekly lighting load [40].

The BBR has a section for energy conservation, with a general requirement that "Buildings shall be designed in such a way that energy use is limited by low heat losses, low cooling demands, efficient use of heating and cooling and efficient use of electricity" [21]: and this is supported at the EU level by the Energy Performance in Buildings Directive EPBD 2010/31/EU [41], which promotes energy efficiency and decarbonization of the building stock by 2050. This includes, among other measures, the establishment of national targets, minimum energy performance requirements for refurbishments and net-zero energy for new buildings, energy performance certificates for sold or rented buildings, minimum requirements for car parking (fostering the use of electric cars), reliance on building automation and control, etc. [41].

The Miljöbyggnad's mandatory requirements related to energy efficiency prescribe building design that avoids cold bridges and air leakage; building design and operation that is energy efficient; maximum solar thermal loads for the summer period to avoid cooling; and that at least 50\% of the energy supply comes from renewable sources [19]. In addition, the standard rewards the use of renewable sources when they surpass 75\% with Silver and $80 \%$-with Gold certifications but require that only $5 \%$ of this needs to be generated on-site. 
Since 2012 Sweden and Norway established a shared electricity certificate system to support renewable electricity production [42]. The 'Vision Sweden 2025' proposes the expansion of renewable energy systems and aims to completely phase out fossil fuel use by 2050 [32]. In addition, in 2015, Sweden also launched the 'Fossil Free Sweden Initiative', which aims to make Sweden a fossil fuel free country by 2045 [43]. The country promotes the use of renewable energy via subsidies, tax regulations and quota systems [44]. However, this system is based on a combination of large and small plants rather than on site-based generation only, with incentives for surpluses to be transferred back to the grid [32]. The system is based on a shared electrical energy output in which hydropower and wind power generation happen at a central level in combination with small-scale solar electricity generation with summer surplus redirected to "hydrogen gas production, refilling of hydropower dams and other storage purposes" [32].

\subsection{Health and Happiness}

This LBC petal contains three imperatives: 'Healthy interior environment', 'Healthy interior performance' and 'Access to nature' [5]. The first devolves building control to occupants through window operation guaranteeing access to fresh air and daylight for a minimum of $75 \%$ of all spaces regularly used. The second sets indoor air quality targets mainly referring to ASHRAE 62 standard for ventilation and a set of indoor air quality tests in compliance with the US Environmental Protection Agency's Compendium of Methods for the Determination of Air Pollutants in Indoor Air, or equivalent methods before and 9 months after occupation [45] but no specification are provided for indoor air temperature and humidity control. The third refers to promoting human-nature interaction through design strategies and elements [45].

The Boverket has a section dedicated to indoor air quality and light quality (nr. 6) hygiene, health and environment [21]. The general regulation Kap. 6 §1. states that buildings should be designed and constructed in a manner that ensures satisfying quality of air, temperature, light without causing damaging effects to health [21]. There are many other very specific requirements set by BBR that illustrates that the Swedish regulations support and promote careful planning of interior environment and the use of healthy materials. For instance, BBR regulation Kap. 6 \$11 says that "Materials and construction products used in a building shall not in themselves, or through their treatment, negatively affect the indoor environment or the local environment of the building, when the performance requirements of these regulations are met" [21]. For more regulations about chemical substances, BBR recommends to turn to the EU regulation EC No 1907/2006 [23], which aims to safeguard a 'high level of human health and environment', by setting rules, amongst others, on manufacturing and use of chemical substances, as well as their assessment methods [21]. More specific rules on air quality are issued also by Public Health Agency of Sweden and Swedish Work Environment Authority [21]. As required by the LBC, BBR also requires buildings to provide good daylight conditions with appropriate intensity and distribution [21].

The Miljöbyggnad [19] is as comprehensive as the LEEDS and BREEAM with regards to indoor environment prescribing maximum levels of Radon; referring to the Swedish Sound Standard SS 25267 for targets related to noise insulation; prescribing targets for air flow; requesting compliance with moisture safety requirements to avoid condensation and water damage (indoors and outdoors); prescribing operating temperatures, relative humidity, air speed, Clo and met, amongst others to be used calculating winter conditions; discouraging the use of cooling systems in the summer through reducing solar gains; and imposing that indoor spaces have at least 1.5\% Daylight Factor. [19].

\subsection{Materials}

The LBC 'Materials' petals has five imperatives: 'Red list' which forbids the use of materials with greatest impact in human and ecosystem health; 'Responsible sourcing' which request purchasing materials from approved providers; 'Responsible materials ' 
which requests project teams to have at least $50 \%$ of the building's wood material coming from FSC, being salvaged or harvested on site with the rest coming from other low-risk sources with content, origin and fair extraction processes proven; as well as divert $80 \%$ construction waste from landfills. 'Living economy sourcing' which requests the use of materials from a short distance from the project site; and 'Net positive waste' which focuses on durability, adaptability and re-use of new materials with their re-integration to the nutrient loop at the end of life [5,46].

The Boverket regulation Kap6 $§ 11$, states that 'Materials and construction products used in a building shall not in themselves, or through their treatment, negatively affect the indoor environment or the local environment of the building, when the performance requirements of these regulations are met' [21]. Regulation Kap6 \$21 says that the air should be free of pollutants that could damage human health. [21]. BBR further directs to regulation (EC) No 1272/200 that targets "Registration, Evaluation, Authorisation and Restriction of Chemicals (REACH)" (European Parliament and European Council, 2006 in [21]). In addition, the Miljöbyggnad has similar demands in relation to building and interior materials, requiring extensive documentation in relation to their safety as well as embodied $\mathrm{CO}_{2}$ [19].

Swedish legislation does not provide specific offset of embodied carbon footprint or request the use of materials in proximity of the project site. However, despite not having prescribed distances to source local materials, the Miljöbyggnad praises reduced embodied $\mathrm{CO}_{2}$ related to the total Environmental Product Declaration (EPD) of materials, which include transportation. The Boverket does not provide information about material sourcing, promotion in the use of salvaged materials only giving general recommendations with regards to durability and structural strength [21]. The Environmental Code, on the other hand, encourages reuse and recycling, as well as responsible management of raw materials to ensure that natural cycles are preserved [27]. In addition, several regulations and initiatives coming from the European Union focus on sustainable supply and extraction of materials, such as Roadmap to a Resource Efficient Europe, EU Action Plan on Circular Economy, etc. [47]. The European Union also has several policy documents on social and business responsibility [48] that aim to promote positive impact on society by business activities.

\subsection{Equity}

The LBC 'Equity' petal is centred in promoting human-scale rather than vehicle-scale places, focusing mainly in restricting the size and percentages of land use for car parking. It also focuses on creating places with universal accessibility (regardless of gender, age, socio-economic class, etc.), including universal access to nature as well as outdoor fresh air and solar rights. It finally focuses also on equitable investment, requiring $0.1 \%$ of total project cost to be donate to charity, and requests transparency and disclosure of business practices of the project team towards promoting an equitable society $[5,49]$.

Requirements related to the use of cars and accessible and sustainable cities were discussed in Section 4.1, which showed that despite efforts in the Boverket to reduce the use of vehicles, ultimate control over land use for car park is devolved to municipalities. The Boverket has separate chapter (Kap3 §1) on accessibility for people with physical disabilities, that is made to increase their mobility within buildings and cities [21], with prescriptive and more stringent demands than those of the LBC. The EU has broad policies on social responsibility and development of jobs and skills in the local economies, such as 'Towards more effective adult learning policies, 'Quality framework for traineeships' amongst others [50], which tackle similar aspect listed in the LBC in relation to promoting an equitable society.

\subsection{Beauty}

The LBC 'Beauty' petal requires project teams to "design features solely intended for human delight and the celebration of culture, spirit and place appropriate to its function 
and meaningfully integrate public art" [51] surveying building users in relation to it [5,51]. It also requests project teams to disclose and share information on building performance and operation to the public with inspirational and educational intents. None of these requirements are covered by the Swedish regulations. However, the PBL states that municipalities should promote "a purposeful structure and an aesthetically pleasing design of the built environment, green spaces, and transportation routes" [24]. One example is Hornsbergs beach park, finished in 2012, which stretches $700 \mathrm{~m}$ along the cost, and provides open and green spaces for city residents and visitors [52].

\section{Validation and Discussion}

Findings from the document analysis basically show that Sweden has already series of regulatory mechanisms to ensure preservation of the natural habitat, promote sustainable transport and stormwater management and reduce consumption of natural resources. Issues related to densification vs. sprawling, show regulations inclined not only towards reducing infrastructure costs but also towards preserving natural habitats and urban infrastructure of all sorts is clearly portrayed as a public good delegating the responsibility for it to be environmentally sustainable to the state with some citizen counterpart, for instance through selling surpluses to the grid. These findings are confirmed and validated in this section via interviews with one architect involved in an LBC project in Sweden plus three public authorities from the Boverket. They focus on the themes of place, water, energy, indoor air quality and materials as these were mainly areas in which overlaps and barriers were found.

Table 1 shows the Swedish regulations overlap with the LBC with regards to safeguarding undeveloped land as well as environmental protection, which is confirmed by the Boverket representative (B2) who particularly stated that environmental protection can be enforced.

B2: "You need to have a building permit and then you need to have an environmental permit too, [for larger buildings] ... and the environmental permit will be handled by the environmental committee. They will go through the specifics of the site, what kind of levels of pollution, what environmental impact it will have and maybe you will need to have a special assessment of the impact on nature, and so on. So, in this case you need both permits to start construction."

An overlap on promoting cycling and the use of public transport has also been confirmed by the architect, but this seems to be more of a work in progress than completely implemented.

A: " .. recently there has been huge development in bicycling. There are very many people who bike in the city, so that is nice. [ . . ] They really have a plan for this. And I think that cities in Sweden, we have just woken up now and think about these things. Because the cars have been like holly cow so far and still are, they take enormous place on land and I hope that in the future we can make car owners to take more trams, trains, or bikes."

Environmental preservation and sustainable mobility align with the densification of cities and limitations in sub-urban growth but do not necessarily change the demand for car parking. In fact, they produce a rebound effect in the use of motorized vehicles by shifting from private use to shared use, with densification offsetting the benefits from sharing, restricting available land which could be used to urban agriculture, since municipalities have the powers to demand for car-park allocation on-site.

A: "Unfortunately, the trend in Sweden is to follow cities like New York with the high-rise buildings, etc., which are very far from natural beauty. [ . . ] If you have a very small place where you do not have much area to cultivate on, [urban agriculture] might be a problem and most municipalities have also a regulation that you should be able to park your car, or in public building cases - to have carparking. [ . . . ] Most of the masterplans really demand that you solve the parking problems and that would take area." 
A notable barrier exposed by the document analysis is the approach to water harvesting and wastewater treatment. Whilst the LBC promotes the in-situ harvesting and management of all wastewaters, the Swedish regulations push for connection to potable water and wastewater networks. This finding was confirmed by most of the interviews with representatives of the public sector clearly stating that if the building owner sill wants to use their own system, they would need to pay the municipality for the service anyway as the infrastructure should be available to all and therefore supported by all (B1). This might lead to future conflicts with the EU Water Framework Directive 2000/60/EC which promotes sustainable community water management in-situ, because in the Swedish vision, drinking water supply is considered of key national interest.

B1: "When the municipality has decided that they will deliver water and wastewater systems, everyone has to be a part of it. Otherwise just some buildings have to pay for all this system. This system is for everyone to use. [ ... I If the owner of the house says they have their own perfect water or their own sewerage system, and the municipality says - no, no, no, ours is much better and that is the common way. In such situations project teams have to go to land and environment court. [ ... ] So, the teams go to courts and then they will decide the final decision and normally they will say-no, you have to be a part of the municipality's system."

However, the Boverket B1 and the architect commented that it is indeed possible to recycle rainwater and greywater in Sweden, and that municipalities have the power to decide and inspect about it.

B1: "It will be the Environmental and Health Protection Board, Environmental department at the municipality, not the building department, who can say which systems you can use or not. [ ... ] When it comes to Environmental Codes environment chapter, the municipalities have their own inspectors."

A: "The municipalities work in different ways even when it comes to sewerage, so sometimes they have their own lists of which techniques and companies you can use ... "

They both, however, highlight potential issues related to health, discouraging recycling for drinking use, with the latter also raising issues related to water security as a potential national problem.

B1: "You have to have the same quality of the water [ ... ] But you can use recycled grey water for other means. There is EU standard for reusing rainwater. And there is EU standard for recycling grey water. But you can use recycled greywater, depending how much you clean it, but you can use it for the toilet, and I know that people use it also for washing machines, but not as drinking water. But if you want to use it as drinking water, it has to fulfil the regulation from drinking water directive. [ ... ] But you can have a problem [ ...] with bacteria legionella in the water. [ ... ] So, it very much depends for what you are going to use it. [...]"

A: "You should be able to use recycled water for cleaning clothes and toilets. But not for drinking. Because such water does not contain the necessary minerals that we need. [... In Sweden we have been so rich in water. [ ... ] I though, oh -if we do not have anything else, we always can sell the water to the rest of the world. But nowadays it is so different, [ ... I In some areas in Sweden, there have been made ditch systems to make usable agricultural land, in order to get rid of the excess water. Now they have such a huge problem with the groundwater, which is not enough now. All the rainwater runs off into the sea, and this is what they wanted then. But nowadays, it is such a big issue, because they have so low levels of groundwater. [ ... ] Now they take salty water from the sea and use a lot of energy to clean it before it can be used. I would never think that this one day could become reality in Sweden."

B1 states it is unlikely that regulations related to drinking water will change but that there are and will be more flexibility in relation to regulations related to wastewater, 
backed up by the EU but people would still have to pay for their share on the infrastructure regardless if they are using it or not.

B1: "We are not going to do anything with the water that is supposed to be drinking water, because its quality should be as good as said in the drinking water directive. But for example, there will be more and more possibilities that you can use and recycle rainwater and greywater for other purposes, like toilets and washing machines and things like that. [ ... ] Buildings would still have to pay for municipal sewerage system."

In this context, public authorities and the architect admit that the LBC standard is more suitable to be applied outside cities or in rural areas, where they would face less regulatory constraints, meaning on-site systems could be installed if meeting Swedish requirements for health and safety.

B1: "When it is just for one family houses when it is not a part of municipal system and it is just small drinking water treatment plants for example for just one or few family houses or very small village, they just have recommendations, but normally it is mandatory to follow the drinking water directive and they are just following the drinking water directive of the EU."

This, however, does not guarantee a smooth approval process because municipalities have their own views in relation to what types of in-situ system should be used.

B1: "They might say-no, we want you to have a standard system-just a septic tank and infiltration system. I know that companies, who make sewerage cleaning systems, they have had problems with municipalities, even though their products are [CE] tested, and municipalities still say-no, we do not believe in these tests. So, in such situations builders can turn to court."

Clashes related to in-situ energy supply vs. connection to the grid are also highlighted in the document analysis. However, the Swedish program to phase out fossil fuels from the grid combining large scale renewable energy generation with small scale solar systems cannot be overlooked as non-sustainable or non-regenerative. Thus, despite flagged as a clash in Table 1, it was not discussed with public authorities' representatives as the document analysis clearly stated this is not an environmental disagreement but a political one. Local generation might, in some cases have not been fully implemented, due to clashes with municipalities and needs to be carefully discussed with regards to local level energy storage provisions as stated by the architect.

A: "Some people in Stockholm have had problems with getting solar panels on the roof, because of the aesthetics and cultural treasure of the building. This applies to existing buildings. But I do not think you would ever have problems with new buildings in this regard. [...] we wanted to work with hydrogen gas, to store the electricity power in hydrogen gas from the summer through the winter. Then you need big tanks for this, and I think they should stay outside the building, because they have risk for explosions. Therefore, you would need some area to put these tanks. In the area's masterplan there was not much technical advices, so I think that we would need to work with the municipality to make this solution possible. So that was an issue."

It is clear from Table 1 that the existing Swedish regulations for indoor environment are already very strong and that, in addition, the Miljöbyggnad requires 24 months of use for buildings to be certified in contrast with the 12 months required by the LBC.

A: "[indoor air environment] is a big field. [ . . . I think we have pretty strong regulations already on the indoor quality. [ . . . ] We have a lot of consultants sitting and planning everything, putting heat exchangers in buildings. But I work with companies that do not want buildings to be so mechanical. They want more natural solutions, for instance, that the building's ventilation functions like termite house, and we have much less heat exchangers. [ ... I I think these consultants have had fights now and then. Because municipalities say that you should have an impact on the indoor environment, like 
adjusting temperature and ventilation. [Even though] these projects are very successful, and people are very satisfied with the indoor air and temperature, and these are extremely energy efficient houses. [ . . . I If you follow system the Miljöbyggnad, they really force you to have daylight in every room. [... ]"

Another notable finding from the document analysis was the decision-making power devolved to municipalities. Interviews confirmed these findings and exposed that many municipalities tend to have additional requirements on building projects than the ones outlined by the national regulations (A and B3), when legally they are not allowed to do so (B2 and B3).

B3: "The thing is that they are forbidden to have different requirements than in the national regulations, but in some cases, they can actually have their demands. These cases are when the municipality is acting as a developer or property owner or when they are selling land, which has no complications with the detail plan, then they can put additional regulations. In other cases, they are forbidden to have different requirements than are stated in the national laws."

Project teams can appeal the decisions made by the municipalities, first in the Lansstyrelsen - a regional authority, and then in the Environmental court and eventually-at the Higher Land and Environment Court (B2).

B2: "I can say that every day you have court cases about this specific matter-when a local building committee asks more than they have the rights to do. When it comes in the hands of the court, they will say-the municipal building committee has no rights to demand this from you and they will send the case back to the committee or they will just say-it is not legal".

In all situations, municipalities can ask the project teams to follow their masterplans when it comes to choosing areas where a certain type of building can be built, or if the building has to be connected to municipal service systems (B1-B3). However, the interplay of multiple regulatory systems concerning the built environment can make decision-making overcomplicated and court cases non-straight forward.

B2: "[ . . ] there are many systems interplaying. There are our (Boverket) guidelines and there are ordinances from the government, the legal bases, the building law, the environmental legislation, the Environmental Code, and ordinances from the government on the environmental matter, so there are many guidelines. [ ... ] definitely, BBR and Environmental Code interact very much. Both of them must be observed. [ ... ] planning and construction and the environmental impact on everything. [ . . ] But there are more rules about different subject matters. Everything usually is handled by the local committee; they usually have one committee on the building and construction and one committee on the environmental impact. They have to follow hierarchy. And they know what is acceptable and what is not, because there have been so many court cases. But sometimes they will still try and ask for something more. Sometimes it is also necessary to check the legal practice, the court cases that go to the highest level. And very often they are highly critical of municipalities and their authorities, so it happens all the time."

The reasons behind why professionals in municipalities are imposing stricter requirements can be that the professionals within municipal building committees have good education about the subjects and they do not necessarily agree with the national regulation.

B3: " $[$... ] the civil servants have a good education, and they want to use their education to make good work in the practical use. The thing is that most practitioners that are handling building permits and other rulings according to the Planning and Building Act, they are not lawyers, but they are experts in their own field. But sometimes they cannot stand that the law says otherwise than they think it should be. So, it is a complex matter"

Interestingly, they can also be political, with a clear push from some municipalities to actually requesting the industry to do better. 
B3: "You have the Environmental party in Sweden and their main interest is to have buildings and infrastructure that is good for the environment, and they want to show that their municipalities are very good place to live in, therefore they want to impose more regulations"

The aforementioned extracts show the interviews not only confirmed the main findings from the document analysis but also provided additional details about the reasoning behind most of them. They highlighted Sweden has a rather stringent environmental law with significant decision-making power devolved to municipalities which are concerned with quality controlling the infrastructure provided and ensuring basic services are accessible to all.

\section{Conclusions}

This study explored what were the barriers and overlaps between the Swedish regulatory system, the Miljöbyggnad national certification system and the LBC. It confirmed and transcended the findings from [15] which states that barriers to implement the LBC are mainly related to regulations and codes by unfolding that, in the Swedish context, they are also part of everyday practices of issuing building and environmental permits, which reflect the ingrained belief from municipalities that project teams should connect to the water, wastewater and energy grids. Contrarily to what was believed by [15], which states that regulatory bodies and public authorities are risk averse to innovative technologies for in-situ water, wastewater treatment and energy generation and that they would therefore impose obstacles to attract investments in green technologies, this work reveals this is actually a conscious political and ideological decision from the welfare state.

Regulatory bodies and public authorities in Sweden see water as primarily a key national interest and together with wastewater collection and energy, a matter of public good. Energy and water infrastructures should therefore not only be provided to all but also collectively funded by all, regardless of any individual decision in using it or not. This collective distributive system sees the LBC self-sufficiency approach, which preaches in-situ harvesting and treatment with in-situ storage to tackle resilience, as primarily individualistic, if public network is available.

In the welfare state, sustainability and resilience become a property of the network and can be considered robust if a flexible generation system is implemented such as the one of combining large and small scale generation backed up by incentives to transfer surpluses to the grid. In addition, the case of Sweden, the devolved power to local authorities granted by the regulatory framework of the welfare state added to a politically green inclination, reflected by the strong role of the Environmental party in many municipalities, seems to promote competition across the country in relation to which city 'does better' in addressing environmental issues. Best-practice cascades up to different layers of the regulatory framework from the creation of city scale outdoor urban spaces to cater for urban run-off up to a national program for decarbonization of the grid, in which renewable energy is provided and guaranteed by the state.

The idea here is not to preach Sweden as a role model with regards to environmental regeneration but rather to discuss it approached environmental challenges from the perspective of it being a matter of the public good. In this sense, this paper opens future avenues to examine the deployment of regenerative standards beyond their technical objectives by exposing that for instance in-situ feedback loops go beyond ecological premises and need to be examined also from their political and ideological perspectives if a proper coupling of science and governance is to be achieved. To this end, future work is needed to concert a clash of ideologies which might reflect on how resilient and sustainable infrastructures can be deployed. After all, when the provision of infrastructure, which desperately needs to happen in a more sustainable and regenerative way, always understood as collectively owned and shared becomes the responsibility of the individual, how will equity, fairness, and justice, to humans and the environment, be ensured? 
Author Contributions: The whole research was done by M.F. under the supervision of C.B.d.S. as part of an MSc Dissertation which is summarized and published as this paper. C.B.d.S. then edited the writing and transformed into this paper. All authors have read and agreed to the published version of the manuscript.

Funding: This research received no external funding and was based on the MSc dissertation from the lead author awarded by Cardiff University in 2020.

Institutional Review Board Statement: The study was conducted according to the guidelines of the Declaration of Helsinki and approved by the Institutional Review Board (or Ethics Committee): Cardiff University Ethics committee. Protocol number: 1923_Mara Parfenovica, date of approval 6 November 2019.

Informed Consent Statement: Informed consent was obtained from all subjects involved in the study.

Data Availability Statement: Interview transcripts are not shared due to privacy issues, i.e., they can disclose information that can lead to tracing back to the individuals interviewed.

Conflicts of Interest: The authors declare no conflict of interest.

\section{References}

1. Petrullo, M.; Morton, B.; Jones, S.A.; Laquidara-Carr, D.; Lubrano, S.; Lorenz, A.; Yamada, T.; Buckley, B.; Logan, K.; Barnett, S. World Green Building Trends 2018; Dodge Data \& Analytics: Bedford, MA, USA, 2018.

2. Sonetti, G.; Brown, M.; Naboni, E. About the Triggering of UN Sustainable Development Goals and Regenerative Sustainability in Higher Education. Sustainability 2019, 11, 254. [CrossRef]

3. Brown, M. Futurestorative: Working towards a New Sustainability; RIBA Publishing: London, UK, 2016 ; ISBN 9781859466308.

4. Yudelson, J. Reinventing Green Building: Why Certification Systems Aren't Working and What We Can Do About It; New Society Publishers: Gabriola Islands, BC, Canada, 2016.

5. International Living Future Institute. Living Building Challenge 4.0; International Living Future Institute: Seattle, WA, USA, 2019; pp. 1-81.

6. Kibert, C.J. Sustainable Construction. Green Building Design and Delivery, 3rd ed.; John Wiley \& Sons, Inc.: Hoboken, NJ, USA, 2016.

7. Darko, A.; Chan, A.P.C. Review of Barriers to Green Building Adoption. Sustain. Dev. 2017, 25, 167-179. [CrossRef]

8. Schade, J.; Wallström, P.; Olofsson, T.; Lagerqvist, O. A comparative study of the design and construction process of energy efficient buildings in Germany and Sweden. Energy Policy 2013, 58, 28-37. [CrossRef]

9. Hankinson, M.; Breytenbach, A. Barriers that Impact on the Implementation of Sustainable Design. 2013. Available online: https:/ / core.ac.uk/download/pdf/54188954.pdf (accessed on 13 October 2019).

10. Mang, P.; Reed, B. The nature of positive. Build. Res. Inf. 2015, 43, 7-10. [CrossRef]

11. Cole, R.J. Net-zero and net-positive design: A question of value. Build. Res. Inf. 2015, 43, 1-6. [CrossRef]

12. Clegg, P. A practitioner's view of the 'Regenerative Paradigm. Build. Res. Inf. 2012, 40, 365-368. [CrossRef]

13. Du Plessis, C.; Cole, R.J. Motivating change: Shifting the paradigm. Build. Res. Inf. 2011, 39, 436-449. [CrossRef]

14. Tainter, J.A. Regenerative design in science and society. Build. Res. Inf. 2012, 40, 369-372. [CrossRef]

15. Eisenberg, D.; Persram, S.; Spataro, K.; Jason, F.M. Code, Regulatory and Systemic Barriers Affecting Living Building Projects; Cascadia Region Green Building Council: Portland, OR, USA, 2009.

16. Freitas, I.A.S.; Zhang, X. Green building rating systems in Swedish market-A comparative analysis between LEED, BREEAM SE, GreenBuilding and Miljöbyggnad. Energy Procedia 2018, 153, 402-407. [CrossRef]

17. Sweden Green Building Council. Certifierade Byggnader. Available online: https://www.sgbc.se/statistik/ (accessed on 11 November 2020).

18. Brown, N.W.O.; Malmqvist, T.; Bai, W.; Molinari, M. Sustainability Assessment of Renovation Packages for Increased Energy Efficiency for Multi-Family Buildings in Sweden. Build. Environ. 2013, 61, 140-148. Available online: https://www.sciencedirect. com/science/article/abs/pii/S0360132312003174 (accessed on 10 November 2019). [CrossRef]

19. Sweden Green Building Council. Miljöbyggnad 3.0. Västerås, Sweden. 2017. Available online: www.sgbc.se (accessed on 15 November 2019).

20. Turk, S.; Quintana, S.N.S.A.; Zhang, X. Life-cycle analysis as an indicator for impact assessment in sustainable building certification systems: The case of Swedish building market. Energy Procedia 2018, 153, 414-419. [CrossRef]

21. Boverket. Boverkets Byggregler (2011:6); Boverket: Karlskrona, Sweden, 2019.

22. Varnäs, A.; Balfors, B.; Faith-Ell, C. Environmental consideration in procurement of construction contracts: Current practice, problems and opportunities in green procurement in the Swedish construction industry. J. Clean. Prod. 2009, 17, 1214-1222. [CrossRef]

23. European Parliament and European Council. Regulation (EC) n. 1907/2006 concerning the Registration, Evaluation, Authorisation and Restriction of Chemicals (REACH). Off. J. Eur. Union 2006. 
24. Sveriges Riksdag. Plan Och Bygglag (2010:900). 2019. Available online: http:/ /rkrattsbaser.gov.se/sfst?bet=2010:900 (accessed on 6 November 2019).

25. Francart, N.; Larsson, M.; Malmqvist, T.; Erlandsson, M.; Florell, J. Requirements set by Swedish municipalities to promote construction with low climate change impact. J. Clean. Prod. 2019, 208, 117-131. [CrossRef]

26. International Living Future Institute. Place Petal Handbook V 3.1; International Living Future Institute: Seattle, WA, USA, 2017.

27. Sveriges Riksdag. Miljöbalk (1998:808); Ministry of Environment: Stockholm, Sweden, 2019.

28. Jordbruksverket. The Swedish Board of Agriculture; Jordbruksverket: Jönköping, Sweden, 2019.

29. McEldowney, J. Urban Agriculture in Europe. Depth Anal. 2017. [CrossRef]

30. European Parliamentary Research Service. Urban Agriculture in Europe. 2017. Available online: https://www.europarl.europa. eu/RegData/etudes/IDAN/2017/614641/EPRS_IDA\%282017\%29614641_EN.pdf (accessed on 6 December 2019).

31. COST-Action Urban Agriculture Europe. Urban Gardening Network Seved; COST-Action Urban Agriculture Europe: Maynooth, Ireland, 2013.

32. Boverket. Vision for Sweden 2025; Boverket: Karlskrona, Sweden, 2014.

33. Uppsala Kommun. Planbeskrivning. Detaljplan för Rackarberget; Uppsala Kommun: Uppsala, Sweden, 2015.

34. International Living Future Institute. Water Petal Handbook V 3.1; International Living Future Institute: Seattle, WA, USA, 2017.

35. European Parliament and European Council. Directive 2000/60/EC of the European Parliament and of the Council of 23 October 2000 Establishing a Framework for Community Action in the Field of Water Policy EUR-Lex-32000L0060-EN-EUR-Lex. 2000. Available online: https:/ / eur-lex.europa.eu/legal-content/EN/TXT/?uri=CELEX:32000L0060 (accessed on 10 November 2019).

36. European Commission. Optimising Water Reuse in the EU; Publications Office of the European Union: Luxembourg, 2015.

37. Stockholms stad. Dagvattenstrategi. Stockholms Väg Till en Hållbar Dagvattenhantering; Stockholms Stad: Stockholm, Sweden, 2015.

38. Swedish Environmental Protection Agency. Wastewater Treatment in Sweden; Swedish Environmental Protection Agency: Stockholm, Sweden, 2014.

39. Havs och Vatten myndigheten. Havs Och Vattenmyndighetens Författningssamling 2016:17; Havs och Vatten Myndigheten: Göteborg, Sweden, 2016.

40. International Living Future Institute. Energy Petal Handbook V 3.1; International Living Future Institute: Seattle, WA, USA, 2017.

41. European Parliament and European Council. Energy Performance of Buildings Directive 2010/31/EU EUR-Lex-32010L0031-EN-EURLex. 2010. Available online: https:/ / eur-lex.europa.eu/legal-content/EN/ALL/;ELX_SESSIONID=FZMjThLLzfxmmMCQGp2Y1 s2d3TjwtD8QS3pqdkhXZbwqGwlgY9KN!2064651424?uri=CELEX:32010L0031 (accessed on 13 November 2019).

42. Swedish Energy Agency. The Electricity Certificate System. 2020. Available online: http://www.energimyndigheten.se/en/ sustainability/the-electricity-certificate-system/ (accessed on 28 November 2020).

43. Fossilfritt Sverige. Roadmaps for Fossil Free Competitiveness I Fossilfritt Sverige. 2015. Available online: http://fossilfrittsverige.se/in-english/roadmaps-for-fossil-free-competitiveness / (accessed on 13 November 2020).

44. RES LEGAL Europe. Renewable Energy Policy Database and Support: Sweden. 2019. Available online: http://www.res-legal. eu/search-by-country/sweden/ (accessed on 28 November 2019).

45. International Living Future Institute. Health and Happiness Petal Handbook V 3.1; International Living Future Institute: Seattle, WA, USA, 2017.

46. International Living Future Institute. Materials Petal Handbook V 3.1; International Living Future Institute: Seattle, WA, USA, 2017.

47. European Commission. Roadmap to a Resource Efficient Europe. 2010. Available online: https://eur-lex.europa.eu/legalcontent/EN/TXT/?uri=CELEX:52011DC0571 (accessed on 29 November 2019).

48. European Commission. Corporate Social Responsibility \& Responsible Business Conduct. 2019. Available online: https: / / ec.europa.eu/growth/industry/sustainability/corporate-social-responsibility_en (accessed on 7 December 2019).

49. International Living Future Institute. Equity Petal Handbook V 3.1; International Living Future Institute: Seattle, WA, USA, 2017.

50. Commission, E. Jobs and Skills in the Local Economy. 2019. Available online: https:/ / ec.europa.eu/info/eu-regional-and-urbandevelopment/topics/cities-and-urban-development/priority-themes-eu-cities/jobs-and-skills-local-economy_en (accessed on 6 December 2019).

51. International Living Future Institute. Beauty Petal Handbook V 3.1; International Living Future Institute: Seattle, WA, USA, 2017.

52. Nyréns. Hornsbergs Strandpark. Nyréns. 2014. Available online: https://www.nyrens.se/projekt/hornsbergs-strandpark (accessed on 7 January 2021). 